\title{
TEORI MORAL ALAMIAH: SATU GAGASAN
}

\author{
(The Natural Moral Theory: An Idea)
}

\author{
Chong Ah Fok \\ chongahfok@yahoo.com
}

Negara Brunei Darussalam

\begin{abstract}
Abstrak
Setelah hampir dua abad sarjana Timur khususnya Melayu menggunakan teori Barat, telah timbul beberapa pandangan atau kesedaran bahawa kebanyakan teori Barat itu tidak begitu sesuai dengan alam kesusasteraan Melayu. Mulai hujung abad ke 20, beberapa orang sarjana dan pakar sastera di Malaysia, terutamanya, telah memulakan usaha untuk menjana teori sastera dan kritikan. Lebih sepuluh teori sastera dan kritikan telah muncul dalam dunia sastera Melayu. Salah satu daripadanya ialah pengkaedahan Melayu janaan Hashim Awang. Teori ini telah diguna pakai oleh beberapa orang mahasiswa dalam kajian tesis, pada peringkat sarjana muda hingga peringkat kedoktoran. Namun begitu, ada beberapa kritikan yang perlu diambil perhatian tentang teori tersebut yang akhirnya muncullah pemikiran baru untuk mewujudkan teori moral alamiah yang berakar daripada prinsip asas Pengkaedahan Melayu itu. Teori ini menekankan pengetahuan dan pengalaman yang terdapat dalam karya sastera, boleh menjadi teladan (mimesis) untuk membijaksanakan manusia. Kedua-duanya merupakan ilmu dalam karya sastera yang boleh didapati secara langsung ataupun melalui pentakbiran, pentakwilan atau pentafsiran penanda dalam karya. Unsur mimesis merupakan sebahagian daripada elemen ilmu dalam karya sastera yang menjadi sumber untuk dimanfaatkan. Kewujudan prinsip mimesis di sini bukan berlaku secara satu hala sahaja tetapi secara satu pusingan. Pembaca dapat mengambil iktibar daripada karya sastera yang dibacanya untuk kesejahteraan hidup beragama, bermasyarakat dan bernegara. Pendeknya, karya sastera terkandung di dalamnya ilmu dunia dan akhirat yang boleh membentuk minda dan jiwa seseorang pembaca di samping menampilkan unsur keindahannya.
\end{abstract}

Kata kunci: Pengalaman, pengetahuan, teladan, mimesis, penanda 


\begin{abstract}
For almost two centuries, Eastern scholars, Malays in particular, have employed Western theories in research. However, this has given rise to the realization that most Western theories are not compatible with the nature of Malay literature. From the end of the 20th century, some literature scholars, in Malaysia especially, began efforts to generate their own theories of literature and criticism. Their efforts have not been in vain. Over ten theories ofliterature and criticism have appeared on the literary scene. One of these is the Malay methodology theory of Hashim Awang (1998). This theory has been adopted by several students for their research theses, at the undergraduate right up to the doctoral level. However, there has been some criticism of the theory that has led to the formulation of a new theory, that of natural morality based on the fundamental principles of the Malay methodology. This theory emphasizes the knowledge and experience available in literature, which is to be used as a model or an ideal to be imitated (mimesis) to enrich human knowledge. The knowledge contained in literary works is to be gleaned both directly and through inference markers. Literature is the source of knowledge, and mimesis is a part of knowledge. Mimesis is not a one-way process but a circular one as readers can learn from reading literary works in order to achieve a harmonious life in the religious, societal and national sphere. In short, literary works contain knowledge of the material world and the hereafter, and are capable of moulding the mind and soul of a reader, apart from being beautiful.
\end{abstract}

Keywords: Experience, knowledge, ideal, mimesis, markers/symbols

\title{
PENDAHULUAN
}

“... Semua bentuk sastera dan seni berusaha mengujarkan sesuatu yang tidak terucap, semua teori sastera dan seni berusaha menerangkan sesuatu yang tidak dapat diterangkan" Liu (1995:4). Pernyataan ini menyatakan kepentingan teori sastera dalam kesusasteraan. Jika sastera dan seni mengujarkan, teori pula bertanggungjawab untuk menerangkan. Sesuatu yang diujarkan masih belum begitu mantap kesannya kepada sasaran. Oleh hal yang demikian, teori perlu diaplikasikan untuk menjelaskan apa-apa yang telah diucapkan. Oleh sebab itu, muncul atau terbentuk beberapa teori daripada formalistik hinggalah ke pascamoden. Kebanyakan teori itu terhasil dari dunia Barat sejak Plato, Aristotle dan Socrates lagi. Dalam pada itu wujud juga teori sastera dari dunia Timur yang tidak kurang pentingnya, seperti dari negara China, India, dan Arab, kemudiannya Malaysia. Salah satu daripada teori 
ini datangnya dari Malaysia, iaitu teori pengkaedahan Melayu yang dijana oleh Hashim Awang dari Universiti Malaya pada masa itu.

Teori pengkaedahan Melayu satu teori yang agak besar namun perlu diperkemas kerana pendekatan yang ada boleh mengelirukan dan bertumpang tindih. Pendekatan itu pula, dalam tulisan beliau yang lain (1998) telah ditukar menjadi teori seperti teori alamiah. Daripada teori itu pula lahir tiga pendekatan atau teori utama yang masing-masing dinamakan sebagai teori gunaan, teori moral dan teori firasat. (Hashim, 1998:143). Sebagai satu teori, tidak sepatutnya ada teori lain sebagai cabang-cabang di bawahnya, iaitu ada teori dalam teori. Oleh itu, seperti yang dinyatakan oleh Mana Sikana (2006) bahawa cakupan teori ini meluas. "Dengan demikian membuka ruang kepada pengkaji lainnya untuk mengkritiknya" (2006:249). Seterusnya beliau dalam buku yang sama mengatakan bahawa teori ini dilihat bersifat eklektif, juga intertekstual. Di dalamnya ada teori sosiologi sastera, agama, kosmologi dan sebagainya." Norhayati juga berpandangan hampir sama dengan Mana Sikana tentang kerencaman teori Pengkaedahan Melayu. Di samping itu beliau menambah:

Kelemahan pengkaedahan Melayu kerana pemakaian yang tidak sepenuhnya asli, sesuai dan belum mantap. Ciri-ciri pengkaedahan walaupun diadaptasi kepada kesesuaian alam dan budaya Melayu, tetapi hampir keseluruhannya merupakan inspirasi daripada teori sarjana Barat seperti pendekatan moral, formalistik, strukturalisme, psikologi, sosiologi dan sebagainya. Selain itu, istilah yang digunakan agak longgar dan terdapat kecelaruan dari segi penggunaan istilah seperti teori, pendekatan, konsep, dan pengkaedahan. Kelemahan juga dapat dilihat pada kewujudannya yang lebih menjurus pada sifat yang tertutup, iaitu teori yang khusus hanya kepada sastera Melayu, tetapi tidak sesuai diaplikasikan untuk kesusasteraan lain. Sekiranya pembinaan teori ini diletakkan dalam konteks yang lebih luas, iaitu dalam arus pembinaan teori sastera dunia, kita mempunyai potensi untuk membuat sumbangan yang lebih global atau sejagat sifatnya.

(Norhayati, 2002:8-9).

Di samping itu, pemisahan dua pengkaedahan alamiah dan keagamaan dalam pengkaedahan Melayu menimbulkan kesan kontradik daripada kenyataan bahawa masyarakat Melayu itu tidak dapat dipisahkan dengan agama Islam. Sewajarnya kedua-duanya wujud dan diwujudkan menyatu secara integral. Demikian juga dengan pendekatan dalam bahagian masingmasing pengkaedahan alamiah dan keagamaan. Terdapat tiga pendekatan yang 
diwujudkan daripada masing-masing pengkaedahan alamiah dan keagamaan. Kewujudan pendekatan itu ada yang bertumpang tindih dan mengulang perkara yang sama. Jadi sukar untuk menentukan fokusnya. Oleh itu kajian yang menerapkan teori ini belum ada yang menggunakannya secara tuntas sebagai satu kesatuan (keseluruhan teori pengkaedahan Melayu). Pengkaji yang pernah menerapkan teori ini dalam kajian mereka biasanya sama ada memilih pengkaedahan alamiah ataupun keagamaan seperti yang pernah dilakukan oleh Chong (2008), Jelani (2000), Ampuan Haji Brahim (2009), Morsidi (2004). Walaupun sudah ada beberapa orang sarjana yang telah menerapkannya dalam kajian mereka di universiti termasuk kajian untuk tesis kedoktoran, namun mereka itu hanya memilih pendekatan tertentu atau gabungan dua atau lebih pendekatan daripada teori pengkaedahan Melayu itu seperti yang dilakukan oleh Zurinah (2010).

Objektif makalah ini adalah untuk mengetengahkan gagasan awal teori baharu dalam dunia kritikan sastera yang dinamakan teori moral alamiah yang berasaskan dan merupakan tranformasi daripada teori pengkaedahan Melayu janaan Hashim (1989). Kewujudannya diharapkan akan dapat menjadi alternatif baharu kepada para pengkritik dan pengkaji untuk mengkaji hasil karya sastera dunia dan juga akan menjadi satu sumbangan kesusasteraan Melayu kepada dunia pada peringkat antarabangsa. Tambahan pula teori ini akan memperlihatkan ada titik temu antara teori yang dilahirkan di Timur dan Barat. Dengan demikian, teori ini mampu menerangkan sesuatu yang tidak dapat diterangkan dalam karya sastera sama ada sastera tempatan mahupun sastera universal.

\section{TEORI MORAL ALAMIAH}

Teori moral alamiah ini bukan sahaja ingin menjenamakan semula teori pengkaedahan Melayu tetapi juga terdapat pemikiran lain tentang prinsip dan konsep asalnya seperti yang diutarakan oleh Hashim (1989). Perkara ini dilakukan setelah mengaplikasikan teori tersebut dan juga meneliti hasil tulisan para sarjana yang telah dinyatakan di atas. Kedua-duanya, prinsip dan konsep, akan mendedahkan sifat hakiki masyarakat Melayu-Islam yang sangat intim dengan alam dan keteguhan kepercayaan kepada agama. Oleh sebab itu, pembahagian seperti dalam teori pengkaedahan Melayu itu tidak lagi dilakukan. Semuanya disatukan secara integral dalam satu kelongsong baharu. 


\section{PRINSIP TEORI}

Prinsip utama teori ini ialah karya sastera ialah kejadian alam yang mengandungi bentuk, proses, sistem, estetik dan kegunaan sama ada dalam bentuk lisan ataupun tulisan yang mengandungi naratif di dalamnya. Kejadian alam itu bersebab, bermatlamat serta bermanfaat. Alam yang dimaksudkan itu mencakupi bumi, langit serta sistem planetnya, meliputi kosmogoni dan kosmografinya, yang dilihat dari perspektif masyarakat Melayu-Islam. Dari segi kosmogoni Melayu-Islam, Hashim (2002:10), menjelaskan bahawa bangsa Melayu melihat alam semesta dalam dua lapis, lapis metafizikal dan lapis fizikal. Metafizikal disebut oleh bangsa Melayu sebagai "alam ghaib”, iaitu bahagian alam yang sepenuhnya berada dalam kelebihan ilmu dan keagungan Tuhan, yang selalunya menjadi wadah tempat berlakunya kejadian bersifat "supernatural" dan ruang kediaman makhluk halus ciptaan Allah. Menurut beliau lagi, "pada alam inilah tersembunyinya kewujudan zat Allah dan segala sifatnya yang maha tinggi dan agung untuk menguasai bukan sahaja alam ghaib tetapi juga keseluruhan alam zahir atau alam fizikal" (2002:10). Di samping itu, alam metafizikal itu termasuk kelembagaan yang meliputi ciptaan manusia seperti keputusan cara menggunakan alam fizikal tersebut. Jadi, alam metafizikal itu dapat juga dimasukkan segala sesuatu interaksi yang ada di sekitar manusia dan yang dapat mempengaruhi perkembangan kehidupan manusia, iaitu kejadian, peristiwa dan apa-apa yang berlaku di dalam dunia ini sama ada melibatkan manusia secara langsung atau secara tidak langsung.

Bagi alam fizikal, termasuklah kosmografi dan fizikal alam yang dapat dilihat, disentuh dan dirasa yang di dalamnya terdapat berbagai-bagai kejadian dan benda serta makhluk yang dicipta Allah dalam keadaan yang jelas, berbentuk secara lengkap dan indah. Menurut Hashim, pembentukan alam fizikal ini mencerminkan sifat kemuliaan dan kuasa keagungan Allah. Di alam fizikal itulah tempat manusia berkembang biak, berfungsi sebagai tempat memberikan kebaikan, menyediakan pengalaman dan ilmu pengetahuan, dan menunjukkan petanda kewujudan Allah.

Semua kejadian dan objek alam itu dinamakan sebagai unsur alam. Dengan izin Tuhan, unsur alam mencipta atau membentuk sesuatu, contohnya burung membuat sarang begitu juga dengan binatang, sama ada sesuatu yang dibuatnya ataupun dirinya sendiri (unsur alam) terbentuk dengan indah dan berfaedah. Demikian juga dengan manusia, statusnya sebagai khalifah di dunia, menghasilkan sesuatu yang lebih daripada unsur alam yang lain. Manusia bukan sahaja pandai membuat rumah tetapi lebih daripada itu. Semuanya 
itu adalah juga dengan izin Tuhan. Antara ciptaan manusia itu ialah karya sastera. Karya sastera berjaya dihasilkan oleh manusia (pengarang) melalui proses interaksi, interpretasi, dan integrasi dengan alam. Oleh sebab itu, dalam teori moral alamiah, alam yang dimaksudkan di sini bukan sahaja objek alam itu per se tetapi juga segala interaksi, interpretasi dan integrasi alam secara horizontal dan vertikal termasuklah proses dalam hubungan tersebut serta kesannya. Dengan itu, teori moral alamiah melibatkan elemen pengarang, karya (teks) dan pembaca.

Asas teori ini melihat elemen yang sama seperti model teori sastera Abrams (1958) dan Liu (1995:14),

\section{ALAM SEMESTA}

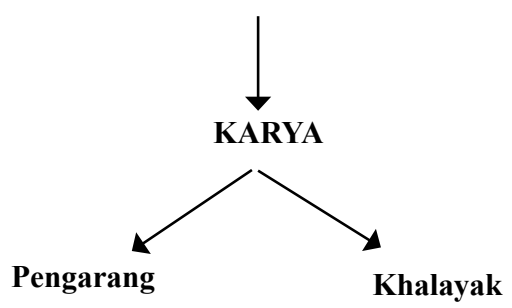

Rajah 1 Skema Abrams.

Dalam model di atas, terdapat empat elemen yang penting dalam teori sastera. Walau bagaimanapun, dari perspektif Melayu-Islam, hubungan elemen itu bukan seperti Rajah 1 di atas kerana di samping empat unsur itu ada unsur yang lebih berkuasa yang membentuk semua itu, iaitu Tuhan. Di samping itu, unsur alam semesta itu termasuk seniman atau pengarang dan juga khalayak atau pembaca. Sementara itu, hasil karya pula dicipta oleh manusia pengarang dengan izin Tuhan dan mengandungi wacana tentang alam dan persekitaran interaksi unsur-unsur tersebut yang berlaku, sedang berlaku ataupun akan berlaku. Berdasarkan prinsip ini kedudukan keempatempat elemen itu dapat digambarkan seperti Rajah 2.

Hubungan elemen Tuhan dengan alam, pengarang dan pembaca bertimbal balik kerana bersangkut paut berkenaan dengan penciptaan elemen-elemen itu. Setelah tercipta elemen, maka elemen tersebut terus berhubung dengan pencipta dan hubungan ini dinamakan sebagai hubungan vertikal. Dapat dinyatakan di sini bahawa dalam hubungan itu, Tuhan memberikan keizinan dan restu 


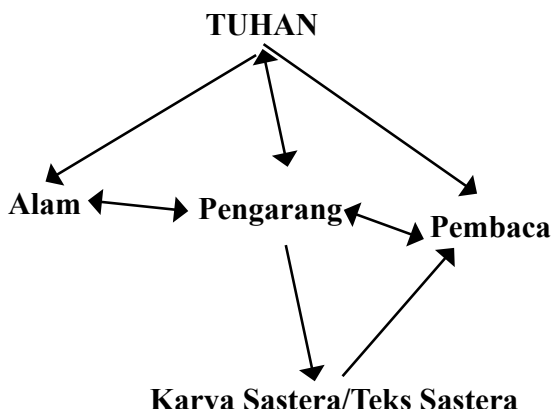

Rajah 2 Hubungan elemen dalam teori moral alamiah.

kepada pengarang untuk melahirkan karya dan sebagai hamba kepada-Nya. Pengarang mestilah menyatakan rasa syukur di samping melahirkan sesuatu yang sesuai dengan ajarannya. Sementara itu, pembaca pula demikian juga, dengan restu-Nya dia dapat memahami apa-apa yang dibacanya dan seterusnya menjananya. Sementara itu, terdapat juga jalur hubungan antara alam dengan pengarang dan pengarang dengan pembaca secara timbal balik. Hubungan ini menunjukkan unsur pengaruh yang berlaku yang memberikan kesan. Dalam hal ini alam memberikan pengaruh kemudian pengarang memberikan maklum balas dengan melahirkan karya, yang merupakan kesan daripada pengaruh itu. Hubungan pengarang dan pembaca pula berlaku secara langsung dan tidak langsung. Secara langsung, seperti yang dinyatakan di atas, pembaca termotivasi dengan kreativiti dan kebolehan pengarang. Pada sisi yang lain, ada pembaca yang terpengaruh kepada pengarang itu melalui media karya sastera daripada kesan pembacaannya.

Hubungan empat unsur di atas dalam rangka teori moral alamiah berbeza daripada apa yang dibuat oleh Abrams (1958) dan juga Liu (1995:13-14). Antaranya termasuklah, hubungan langsung antara penulis dengan pembaca tidak berlaku dalam skema yang dibuat oleh Liu kerana pendapat beliau pengarang atau penulis hanya berhubung melalui karya sastera. Namun, perlu diingat bahawa, pengarang dan pembaca adalah juga unsur alam. Pengarang mungkin juga berinteraksi dengan pembaca yang berperanan sebagai unsur alam yang lain yang boleh menimbulkan ilham kepada pengarang. Di samping itu, hubungan ini juga berlaku apabila pembaca itu sendiri akhirnya menjadi pengarang bukan sahaja terilham daripada karya sastera, tetapi juga termotivasi oleh pengarang asal karya sastera tersebut. Pandangan ini sesuai dengan pendapat Liu yang mengambil kira sebelum 
proses kreatif pengarang dan selepas pengalaman estetik pembaca. Selain itu, hubungan alam dengan pembaca juga berlangsung secara timbal balik melalui pengarang, kesan daripada karya sastera yang telah dibacanya. Pengalaman yang diperoleh oleh pembaca itu akan mempengaruhi tindakan dan interaksinya dengan alam.

Satu lagi prinsip yang terkandung dalam teori ini yang perlu dijelaskan juga ialah moral. Moral dalam konteks teori moral alamiah ini bukan moral yang difahami umum, iaitu pengajaran atau panduan, tetapi lebih menekankan ilmu kehidupan, pengetahuan dan pengalaman yang terdapat dalam karya sastera. Dalam proses penciptaan alam itu terdapat pengalaman yang boleh dijadikan pengetahuan. Sama ada proses penciptaan objek alam ataupun kejadian yang berlaku akan melibatkan pengalaman. Sebagai contoh, sepohon pokok yang tumbuh, tumbesarannya tidak berlaku sekelip mata. Pohon ini mengalami proses. Proses itu membentuk pengalaman dan ilmu yang boleh dimanfaatkan atau berfaedah. Demikian juga dengan kejadian manusia dan unsur alam yang lain. Hal ini berlaku juga dalam penciptaan karya sastera, apa-apa pun genrenya. Dalam novel umpamanya, mendedahkan kehidupan watak-watak yang digambarkan sama seperti manusia biasa. Dalam naratifnya terdapat pengalaman watak, iaitu semasa dia melalui kehidupannya yang didedahkan oleh penulis secara beransur-ansur. Pengalaman Lahuma dalam Ranjau Sepanjang Jalan (1997) hidup sebagai pesawah dan mempunyai keluarga yang hidup tersepit. Novel Shahnon ini bukan sahaja mengandungi pengalaman tetapi juga ilmu kehidupannya. Pengalaman dan pengetahuan ini menjadikan karya sastera itu sebagai satu entiti yang berfaedah. Di situlah juga letaknya keindahan sesuatu karya sastera itu. Jadi, berdasarkan teori moral alamiah ini, sesuatu karya sastera itu mestilah berfaedah dan indah. Kedua-duanya wujud berdampingan dan tidak pernah berpisah.

Kesimpulannya, prinsip teori moral alamiah ini ialah karya sastera itu kejadiannya sama seperti unsur alam yang lain, yang dibentuk oleh alam menjadi objek alam dan mengandungi subjek alam yang bermanfaat kepada alam. Karya sastera itu sendiri merupakan sebahagian daripada alam, iaitu sebagai objek dan juga sebagai subjeknya. Sebagai objek, karya sastera itu dilihat dari segi genre, bentuk dan persembahan isinya. Sementara itu, sebagai subjek pula, naratif dalam karya sastera itu dianggap sebagai mimpi (salah satu daripada kejadian alam juga). Kewujudannya menjadi sumber yang dapat dimanfaatkan dalam kehidupan di dunia nyata dan juga di alam fana. Jadi, karya sastera yang baik, tidak wujud dengan sia-sia. Kejadiannya melalui proses yang kompleks yang melibatkan pengalaman dan ilmu sama ada yang 
telah berlaku, sedang berlaku dan mungkin akan berlaku. Sebahagiannya ada atau dapat dikesan dalam karya sastera yang akan dimanfaatkan oleh pembaca (alam). Kemanfaatannya itu boleh dikecapi melalui naratifnya secara langsung ataupun secara tidak langsung kerana kejadian dalam naratif mungkin rencam seperti keadaan alam. Dengan demikian terdapat naratif yang mungkin masuk akal atau sebaliknya. Perlu ada usaha untuk mendapatkan maknanya yang mungkin berlapis atau berganda. Karya sastera sebegini boleh dianggap sebagai kitab yang dapat dijadikan sebagai panduan, teladan, sumber inspirasi dan rujukan dalam pelbagai bidang kehidupan di dunia dan di akhirat.

\section{KONSEP}

Teori moral alamiah ini dapat difahami dengan penjelasan konsep pada elemen penting seperti yang diterangkan di atas, iaitu pengarang, teks dan pembaca. Selepas penjelasan elemen itu akan diturunkan pula konsep umum teori ini.

\section{Pengarang}

Alam bukan sahaja sebagai sumber inspirasi tetapi juga sebagai pelaku yang aktif. Segala yang melata dan melayang di udara itu ialah unsur alam. Manusia (pengarang) merupakan sebahagian daripada alam seperti bumi, pokok, pelukis, binatang, burung, dan sebagainya. Unsur alam itu sebagai objek, dengan kehendak-Nya, mencipta sesuatu untuk kegunaannya dan juga kegunaan unsur alam yang lain. Sebagai contoh, sungai yang dijadikan oleh Tuhan boleh membentuk pulau (delta) dengan memendapkan kelodak tanah yang dihakisnya di bahagian hulu sungai. Demikian juga binatang seperti burung dapat mencipta sarang sebagai hasil karyanya. Jadi, manusia sebagai makhluk yang paling pintar daripada segala makhluk ciptaan Tuhan dapat menghasilkan pelbagai unsur alam. Perkara ini berlaku akibat interaksi antara alam (manusia dan sesama manusia, manusia dengan alam). Antara perkara yang dihasilkan oleh manusia ialah rumah, jalan raya, kapal terbang dan banyak lagi yang lain. Penghasilan semua objek itu sama juga dengan hasil karya sastera yang dapat dijelmakan dalam bentuk buku oleh pengarang.

Seperti yang dinyatakan sebelum ini, pengarang ialah manusia ciptaan Tuhan (bentuk fizikal alam), yang diberikan restu untuk mengarang. Terdapat berjuta-juta manusia di dunia ini, namun bukan semuanya yang boleh mengarang karya kreatif. Manusia yang direstui oleh Tuhan sahaja yang mampu melahirkan karya kreatif yang menepati standard tertentu. Jadi, 
penjelasan persoalan di atas dapat menjelaskan bahawa ciri pengarang yang melahirkan karya sastera itu perlu ada kuasa tambahan, iaitu dengan keizinan Tuhan. Keadaan ini seolah-olah pengarang itu sudah ditentukan oleh Tuhan sejak lahirnya. Mungkin hasrat itu berlaku cepat atau lambat dalam hidupnya, tidak menjadi persoalan. Ketentuan Tuhan akan berlaku apabila sampai masanya. Di samping itu, pengarang perlu pengalaman dan pengetahuan yang diadun dalam kreativitinya. Dengan demikian, pengarang, berdasarkan pengalaman dan pengetahuannya, mencipta karya sastera dengan ada tujuan dan sebab. Karya sastera yang tercipta bukannya dicipta secara sia-sia. Ada sesuatu yang menggerakkan hatinya untuk mencipta yang diharapkan oleh penulis akan dinikmati oleh pembaca atau pendengar.

Konsep pengarang seterusnya ialah bertanggungjawab terhadap apaapa yang telah dilahirkannya (Maman, 2012), yang sesuai dengan konsep masyarakat Melayu-Islam. Walaupun pengarang disatukan ataupun dikekalkan kewujudannya dengan hasil karyanya, hal ini tidak mengganggu usaha pengkaji atau pengkritik untuk mendapatkan kemanfaatan karya yang dihasilkannya. Tanggungjawab yang dikatakan perlu dipikul oleh pengarang itu sebagai tanda bahawa karya sastera itu ada penciptanya. Setiap yang tercipta itu mesti ada dengan tujuan yang memberikan kesan kepada pembaca. Hasil karya yang baik mengandungi banyak manfaat yang boleh dipilih oleh pembaca. Pilihan di sini bukan antara yang baik dan yang tidak baik. Jika dualisme pilihan itu demikian bererti karya sastera itu tidak menghidangkan sesuatu yang berfaedah positif. Pilihan yang perlu dibuat oleh pembaca adalah untuk memilih mana yang terbaik daripada yang baik-baik itu. Inilah merupakan kebijaksanaan pengarang dalam hal tanggungjawabnya melahirkan karya sastera.

\section{Teks}

Teks dalam teori moral alamiah ialah objek (fizikal) dan sekali gus sebagai subjek (metafizikal). Teks sebagai objek kerana kejadiannya sama seperti unsur alam yang lain, berbentuk, dapat dipegang dan dilihat. Kewujudannya sama seperti unsur alam yang lain contohnya sarang burung, iaitu hasil karya burung. Dalam hal ini Muhammad (2000) mengatakan bahawa teks itu mencakupi skop yang luas bukan sekadar cerita dalam sastera. Di sini teori moral alamiah menegaskan skopnya yang luas itu meliputi dalam dua bentuk yang disebutkan di atas, fizikal dan metafizikal.

Teks sebagai objek wujud secara fizikalnya ialah wacana sastera sama ada bercetak dalam bentuk buku atau pun lisan yang dituturkan daripada 
satu generasi kepada satu generasi yang berikutnya. Dalam hal ini, Wellek dan Warren (1988:230) menyebutkan kewujudan sesebuah karya sastera itu sebagai "artifak" yang terkandung di dalamnya pelbagai genre sastera. Dalam sesuatu karya sastera itu mengandungi naratif yang dipersembahkan atau ditulis oleh dalang atau pengarang dengan pelbagai gaya, bentuk, teknik, dan nada. Karya sastera ini mencontohi keadaan alam yang diciptakan oleh yang maha kuasa. Kewujudannya mengandungi kepelbagaian di samping adanya keseimbangan dan keharmonian gabungan atau adunan semua keadaan itu dalam sesuatu naratif menimbulkan keindahan. Kesemuanya itu terdapat dalam ekosistem alam, dan dalam kesusasteraan boleh kita namakannya sebagai ekosistem teks. Dasar kewujudan ekosistem teks itu ialah huruf atau aksara yang melahirkan bunyi dan perkataan sama ada dalam bentuk lisan ataupun tulisan. Aksara itu berperanan membentuk cerita yang membina naratif dalam karya sastera. Dalam bahasa Melayu ada 26 huruf abjadnya. Dengan bilangan terhad itu, abjad mampu melahirkan beribu-ribu malah jutaan muka surat dijadikan buku yang diterbitkan. Buku-buku yang diterbitkan itu tebal-tebal dan menjadi salah satu daripada objek alam.

Teks sebagai subjek dibicarakan dalam lingkungan metafizik, berhubung dengan proses penciptaannya yang melibatkan pengalaman dan pengetahuan yang mengandungi makna. Prosesnya sama seperti pembentukan unsur alam yang melalui pengalaman yang kompleks dan misteri. Semuanya itu ada pada pengetahuan Yang Maha Kuasa sahaja yang semua itu tidak kompleks dan bukan misteri baginya. Teks dalam konteks ini ialah naratif dalam wacana sastera yang pembentukannya dizahirkan dengan menggunakan media bahasa. Jadi, prosesnya melibatkan jalan yang panjang dan juga melibatkan psikologi yang bersifat idiosinkratik pengarang. Antara pengalaman yang panjang itu ada yang melibatkan pendidikan, iklim budaya zaman, pola kehidupan masyarakat, kepercayaan, falsafah dan politik negara. Sebahagian pengalaman tersebut menyatu pada sesuatu masa untuk melahirkan sesuatu karya. Pada masa yang lain akan berlaku lagi penyatuan tetapi dalam bentuk yang berlainan. Proses ini merupakan "kekayaan alam" yang ditakdirkan untuk pengarang. Oleh sebab itu, seorang pengarang, dengan dasar pengalaman yang dinyatakan di atas, mampu melahirkan banyak teks sepanjang hidupnya.

Pengalaman dalam teks itu berlaku dalam dua dimensi, iaitu dimensi pelahirannya dan dimensi yang dilahirkan. Dimensi yang pertama itu ialah pengalaman pengarang (pengalaman dalaman dan pengalaman kreatif) diterapkan dalam teks ketika dalam proses penciptaannya. Dalam dimensi yang kedua pula ialah pengalaman watak dalam naratif yang terlahirkan itu 
dalam kosmos naratifnya. Pengalaman yang kedua ini hasil janaan pengarang sepenuhnya (kesan daripada pengalamannya). Kedua-dua dimensi pengalaman ini merupakan sebahagian daripada makna yang dianggap sebagai mimpi atau impian (wawasan) pengarang dalam teks. Mimpi ini misteri sifatnya kerana naratif untuk mendedahkan pengalaman itu berlaku seperti di alam ghaib. Kedua-dua pengalaman ini bertemu pada satu titik yang membentuk asosiasi pengalaman pengarang dan watak. Kedua-dua dimensi struktur pengalaman itu berasosiasi dalam naratif secara bertindan seperti yang digambarkan dalam rajah Venn dalam Rajah 3.

\section{Asosiasi pengalaman pengarang pada pengalaman watak}

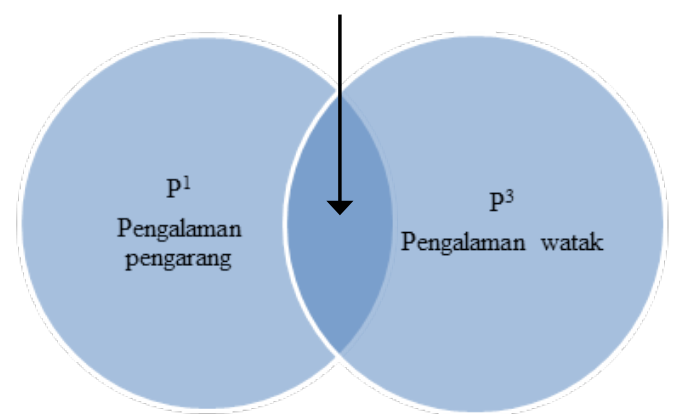

Rajah 3 Struktur pengalaman dalam naratif.

Pada Rajah 3, struktur pengalaman P1 ialah pengalaman yang sebenar yang dialami oleh pengarang dalam kehidupan hayatnya. Sementara itu, pengalaman $\mathrm{P} 3$ merupakan pengalaman watak yang digarap oleh pengarang berdasarkan daya kreatifnya. Pengalaman tersebut tidak terlepas dalam alam budaya pengarang yang merupakan impian atau mimpinya. Dalam perspektif teori moral alamiah interaksi para watak dan segala yang terdapat dalam naratif itu (pengalaman) dikatakan sebagai pengaruh alam sekitar. Pengaruh ini juga dinamakan sebagai peniruan mengikut konsep Plato dan Aristotle. Pengarang telah melalui segalanya (alam sekitarnya) yang terkumpul dalam pengalamannya. Segalanya itu, setelah dijaring dan disaring, diturunkannya dalam bentuk karya sastera. Jadi apa-apa yang dinukilkannya itu bukan sesuatu yang telah dua kali terpisah daripada realiti semuanya seperti pandangan Plato. Terdapat juga sebilangan teks pengarang yang sama dengan pembuat kerusi yang sekali terpisah daripada realiti. Jadi, dalam teori ini usaha pengarang itu belum terlalu jauh daripada realiti atau kebenaran. Apa-apa yang terdapat 
dalam teksnya ialah objek alam dengan segala interaksi atau fenomena yang berlaku secara vertikal dan horizontal. Ia sepatutnya berlaku secara konsisten dalam semua keadaan, iaitu sinkronik dan diakronik yang pragmatik.

Di samping pengalaman, dalam naratif teks juga mengandungi ilmu dan pengetahuan empirikal dan intuitif yang merupakan sebahagian daripada makna teks. Hal ini sama dengan objek alam yang lain yang terdapat ilmu dan pengetahuan di dalamnya, secara tersirat ataupun tersurat. Jadi karya sastera apa-apa pun genrenya bukan sekadar mengetengahkan cerita dalam teksnya tetapi mengandungi makna. Seperti yang dinyatakan oleh Awang Azman, (2016:9):

Pengkaryaan bukan sekadar bercerita, tetapi menyampaikan suatu makna yang penting kepada khalayak pembaca, sama ada berbentuk konflik hidup, gagasan pemikiran, atau reaksi terhadap persekitarannya, serta pengemukaan persoalan yang segar, tahan uji dan dapat membijaksanakan pembaca. Penggunaan bahasa yang sesuai dengan persoalan yang diungkapkan dan penggunaan strategi naratif untuk menggembleng keseluruhan penceritaan dapat memberi kesan yang maksimum ... keindahan kesasteraan.

Ilmu pengetahuan adalah antara makna yang dipaparkan dalam karya sastera itu secara langsung atau sebaliknya dalam naratifnya tentang pelbagai aspek kehidupan yang boleh memperkaya pengetahuan pembaca. Perkara tersebut merupakan buah daripada pengalaman yang terdapat dalam karya sastera itu. Dalam hal ini karya sastera itu mencontohi kitab yang diturunkan oleh Tuhan kepada umatnya. Dalam kitab al-Quran, untuk memaparkan ilmu dan doktrin disertakan dengan cerita seperti yang terdapat dalam Surah Yusuf(Ainon, 2011). Dengan cara demikian, diharapkan ilmu yang hendak disampaikan itu akan masuk meresap dalam jiwa pembaca dan akhirnya dapat dimanfaatkan dalam kehidupan. Walau bagaimanapun, kadar ilmu dalam sesuatu karya sastera itu tidak sekali-kali dapat dibandingkan dengan kitab suci.

Telah banyak diperkatakan tentang pengalaman dan pengetahuan, iaitu makna yang terdapat dalam teks. Namun demikian, tidak bermakna teori ini membelakangkan keindahan dalam teks malah merupakan sebagai pelengkap. Shahnon (1993:3-4) mengatakan bahawa karya sastera itu ada dua tujuan; keindahan dan kemanfaatan. Dengan keindahan, apa-apa yang ada dalam objek alam itu menjadi perhatian kepada manusia. Perhatian yang dimaksudkan di sini bukan hanya ditonton tetapi dinikmati dan juga diambil iktibar (makna teks). Dalam hal ini, elemen keindahan dalam teks itu pelbagai, 
meliputi dari segi bentuk dan juga isinya. Penilaian tentangnya memang bersifat subjektif. Tidak ada satu kriteria yang khusus yang menentukan sesuatu itu dikatakan indah. Keindahan berubah-ubah mengikut keadaan sama dengan objek alam umpamanya sepotong kayu yang terdampar di tepi pantai. Bagi para enviromentalis menganggapnya mencemarkan alam, tetapi bagi jurugambar yang ahli, kayu tersebut suatu keindahan yang mengandungi pelbagai cerita yang boleh menambah pengalaman dan pengetahuan. Apa lagi jika sepotong kayu itu dihinggapi oleh seekor burung atau didampingi oleh seorang gadis yang cantik lalu diambil gambar mereka.

\section{Pembaca}

Pembaca (pengkaji atau pengkritik) juga ialah objek alam sama seperti pengarang. Perbezaan keduanya terletak pada kemampuan mencipta (kecuali pembaca juga pengarang). Dalam hubungan ini, pembaca ialah pelengkap teks yang dicipta oleh pengarang. Setelah teks tercipta menjadi objek dalam alam realiti seperti buku dan seumpamanya, objek ini tidak bermakna apaapa. Selepas dicetak, buku akan tinggal diam di tempat buku ini disimpan. Jika di simpan di perpustakaan, buku itu akan kekal di situ dengan nilai mukanya yang ada (harga buku itu). Jadi di tangan pembacalah teks itu terserlah faedahnya dan kegunaannya melalui pengalaman estetik pembaca. Pembaca dapat mengambil iktibar daripada teks itu dari segi keindahan dan maklumatnya, sama ada untuk diri, masyarakat dan negara.

Pengalaman dan pengetahuan yang ditawarkan dalam karya sastera itu memberikan perubahan kepada pembaca yang mendorongnya untuk berubah seperti makna yang ditawarkan dalam naratif karya yang akhirnya akan membentuk kehidupan (alam). Hubungan alam (kehidupan) dengan karya (peniruan 1) merupakan interaksi pengarang dengan alam. Interaksi ini melalui pelbagai proses yang agak panjang termasuklah kemampuan naluri dan inteleknya. Sementara itu, hubungan pembaca dengan penikmatan naratif teks (peniruan 2) melalui proses yang sedikit berbeza dengan proses yang dilalui oleh pengarang. Proses akhir pembaca ialah kembali kepada alam kerana hasil penikmatannya pada naratif karya sastera itu akan menjadi fenomena baharu dalam kehidupannya dalam hubungannya sesama manusia dan juga kepada pencipta (berdasarkan ilmu dunia dan akhirat yang ditawarkan dalam teks). Oleh itu, rantaian proses pengaruh atau peniruan itu tidak berlaku secara linear, tetapi berlaku dalam bentuk yang berulangulang (satu bulatan) sehingga membentuk kesempurnaan yang abadi manusia 
itu. Pembentukan itu boleh berlaku dalam berbeza-beza waktu. Jadi, di sini pembaca itu sebagai pentafsir pada teks yang diusahakan oleh pengarang. Berdasarkan penjelasan di atas, teori moral alamiah mempunyai konsep dan prinsip teori alamiah secara integral, iaitu:

(1) Teori moral alamiah melihat karya sastera itu sama konsepnya dengan alam ciptaan Tuhan. Kejadiannya berstruktur, dinamik, ada kesatuan, keselarasan dan keharmonian, kepelbagaian dan keindahan (estetik) serta yang penting mempunyai kepentingan kepada manusia. Perbezaan antara kedua-duanya ialah kejadian karya sastera itu berlaku atas kehendak atau restu Tuhan melalui usaha manusia tertentu atau terpilih (pengarang atau penulis) untuk kepentingan semua manusia (melalui pembacaan karya sastera ataupun tulisan tentang karya seni tersebut).

(2) Teori ini melihat isi karya sastera seperti mimpi dan di dalamnya berkemungkinan ada dua lapisan makna; tersurat dan tersirat. Isi tersurat ialah lapisan permukaan, dan yang tersirat pula lapisan dalamannya. Antara isi tersurat, di samping cerita, ialah persoalan yang ditonjolkan secara sedar mahupun bawah sedar pengarang hasil interaksi atau konteksnya dengan alam persekitaran sosialnya. Isi tersirat pula terpendam dalam cerita bersifat lebih anjal dan tidak terhad oleh masa. Untuk mendapatkan makna tersirat itu, pembaca perlu peka mentakbirkan elemen penting pada karya sastera yang terdapat dalam lapisan permukaan seperti watak dan perwatakannya (termasuk tindakannya), peristiwa yang signifikan dalam naratif serta bentuk karya sastera. Karya sastera yang baik mengandungi makna yang lebih besar dan penting untuk dimanfaatkan oleh manusia.

(3) Teori ini dapat digunakan untuk menganalisis kemanfaatan karya sastera. Kemanfaatan yang lebih penting itu ialah ilmu dan pengalaman yang terdapat dalam karya sastera. Kedua-dua perkara tersebut menjadikan karya sastera itu berkonsepkan kepustakaan dan berhikmah untuk manfaat manusia. Konsep ilmu yang terkandung di dalamnya tidak sama dengan ilmu dalam disiplin sains. Ilmu dalam karya sastera lebih dinamik dan tidak akan ketinggalan zaman.

(4) Teori ini berpendapat bahawa isi karya sastera dapat dilihat melalui tindakan serta interaksi watak dengan alam (meliputi semua yang dicipta oleh Tuhan dan juga alam yang dijana oleh makhluk ciptaan-Nya secara 
abstrak mahupun konkrit). Interaksi itu mewujudkan peristiwa dalam cerita (seolah-olah mimpi, hasil janaan penulis dengan bakat kreatifnya) yang bukan sahaja menjadi pengalaman watak, tetapi juga menyediakan contoh dan teladan, perbandingan dan iktibar kepada pembaca. Pengalaman ini akhirnya akan menjadi pengetahuan kepada pembaca yang boleh digunakan sebagai panduan dalam kehidupan manusia sehari-hari.

(5) Teori moral alamiah mementingkan isi dan juga bentuk. Hal ini selari dengan falsafah alam ciptaan Tuhan yang semuanya bersebab dan mempunyai kepentingannya masing-masing walau bagaimana buruk sekalipun keadaan fizikalnya. Kedua-dua elemen tersebut mewujudkan tiga teras utama; teras kebajikan, ketakwaan dan ketatasusilaan dalam karya sastera. Dengan demikian teori ini mengangkat karya sastera pada tahap yang tinggi kerana karya sastera itu dianggap boleh memanusiakan manusia, iaitu karya sastera boleh mengubat jiwa dan emosi manusia, memperkaya motivasi, mampu mentransformasikan tindakan, memberikan pulangan rezeki, dan yang lebih penting mentauhidkan Allah.

\section{PENGAPLIKASIAN}

Teori moral alamiah ini tidak membicarakan teks sebagai sastera sahaja tetapi membicarakan teks itu sebagai pustaka, seperti halnya alam ini yang terdapat banyak ilmu dan pengetahuan di dalamnya. Termasuk di dalamnya unsur keindahan yang boleh memanusiakan manusia melalui pengiktibaran ataupun penyaluran ilmu. Oleh hal yang demikian, pengaplikasian teori ini boleh dibuat melalui perspektif pengarang dan deskriptif pembaca secara berasingan ataupun disatukan. Elemen pustaka dalam teks itu boleh ditimbulkan melalui kedua-dua sudut pandangan tersebut. Pengkritik yang mengaplikasikan teori ini dari sudut pandangan penulis akan lebih cenderung untuk memberikan bimbingan tentang cara seharusnya pengarang itu menulis karya sastera yang mempunyai nilai tinggi (konsep pustaka). Pengkritik yang sedemikian tentu mempunyai kayu ukur tertentu yang selari dengan prinsip dan konsep teori moral alamiah ini. Pengkritik atau pengkaji yang menggunakan sudut pandangan pembaca untuk mengaplikasikan teori ini akan boleh menggunakan unsur luaran dan dalaman kerana kedua-duanya bertaut untuk memberikan makna yang bermanfaat. Unsur luaran ialah teks (bentuk) dan pengarang (latar belakang serta proses pengarangannya sehingga terbitnya karya sastera itu). Sementara itu, unsur dalaman pula 
khusus naratif teks dalam karya (isi). Dikotomi ini meliputi semua genre sastera itu tanpa mengira sama ada sastera klasik mahupun kontemporari. Namun, untuk mendapatkan maknanya akan melalui dua situasi secara horizontal dan vertikal. Situasi horizontal ialah makna naratif yang ditawarkan secara tersurat, sementara situasi vertikal pula memerlukan pentafsiran bagi makna yang tersirat. Biasanya pentafsiran itu tidak terlalu rigid, tetapi bergantung pada latar belakang budaya serta kebijaksanaan penganalisis. Makna tersirat itu biasanya bersifat arbitrari secara paradigmatik diakronik ataupun sinkronik. Sama ada dalam bentuk horizontal mahupun vertikal, unsur luaran dan dalaman terlibat secara langsung.

Sudut pandangan pembaca ini akan mendedahkan fungsi sastera itu kepada masyarakat dan negara. Dalam hal ini penganalisis boleh menggunakan istilah dalam teori struktural seperti persoalan, tema dan seumpamanya. Pokoknya, dalam analisis yang menggunakan teori ini, akan menyingkap pengalaman (pengarang dan watak) dan pengetahuan (maklumat tindaktanduk manusia) dalam teks yang dapat memperkaya pengalaman, untuk pedoman dalam kehidupan. Perkara ini diakui oleh Muhammad (2014). Hal ini dapat dilihat daripada pengalaman watak-watak berinteraksi dalam naratif teks yang kemudiannya menjadi pengetahuan pembaca. Naratif dalam teks itu misteri sifatnya. Dengan demikian, analisisnya perlu dilakukan dengan melihat makna tersurat dan tersirat. Pengkaji atau pengkritik perlu mendedahkan makna teks sama ada dari aspek sosiobudaya, sosioekonomi dan sosiopolitik termasuk aspek keagamaan untuk menjadi pedoman atau sempadan kepada manusia membuat pilihan dalam mengharungi hidup ini di dunia fana dan di akhirat. Pilihan yang dimaksudkan di sini bukannya antara positif dengan negatif, tetapi antara positif dengan lebih positif. Pengkritik boleh memfokuskan sesuatu ilmu (maklumat) yang dipaparkan dalam sesebuah karya lalu membicarakan dan menghuraikannya berpandukan pengalaman watak yang melaksanakannya, sebagai contoh, memfokuskan ilmu rumah tangga, meningkatkan ketakwaan. Di samping itu, penganalisis atau pengkritik perlu boleh mendedahkan keindahan sesebuah karya sastera Melayu-Islam itu seperti yang disarankan oleh Braginsky (1994), Muhammad (2000) dan Abdul Halim (2012). Penganalisisannya juga boleh digunakan dalam sastera bandingan dengan membandingkan kesejajaran dua buah karya sama latar belakangnya atau sebaliknya. 


\section{KESIMPULAN}

Teori moral alamiah ini boleh menjadi alternatif kepada para pengkaji yang mengkaji (menerangkan sesuatu yang tidak dapat diterangkan) karya sastera Melayu. Berdasarkan penjelasan di atas, teori ini tetap berakarkan masyarakat Melayu-Islam yang sangat akrab hubungannya dengan alam. Seperti yang dipaparkan pada prinsipnya dan konsepnya, teori ini mementingkan kesan, kegunaan,dan kemanfaatan atau faedah teks bagi sesuatu karya sastera. Perkara ini perlu dihuraikan, dan diselongkar dalam sesuatu teks. Teori ini mengangkat semua genre teks karya sastera sama ada lisan dan tulisan kerana membandingkannya dengan unsur alam yang dicipta oleh Tuhan dengan ada nilai faedahnya untuk dimanfaatkan kepada makhluk termasuklah manusia. Tinggi atau rendahnya mutu teks itu bergantung pada kebijaksanaan pembaca untuk menilainya dan pengarang menciptanya.

Akhirnya disarankan teori ini dapat diaplikasikan oleh para pengkaji terutamanya di pusat pengajian tinggi Melayu di negara ASEAN kerana sepatutnya pusat pengajian ini menjadi inkubator untuk mempraktikkan teori janaan sarjana tempatan. Gerakan ini bukan bermaksud hendak memutuskan hubungan dengan dunia Barat tetapi bagi menyeimbangkannya. Segala kekurangan dan kelemahan teori ini perlu diterima dengan sikap dialektik oleh para sarjana tempatan dengan cara menampungnya dan menjadikannya lebih perkasa dan tahan uji. Malah, pemikiran baharu untuk memperkukuh teori ini adalah sangat dialu-alukan. Jika sikap seperti ini berlaku, teori ini akan menjadi kukuh dan menambah satu lagi teori sastera. Dunia kesusasteraan akan lebih meriah kerana kewujudan teori dari Timur, dan diharapkan menjadi teori alternatif kepada sarjana Barat juga. Perkara seperti ini boleh berlaku kerana sikap demokratik yang terdapat dalam teori sastera itu dalam dunia global pada masa ini. Dalam pasaran terbuka seperti itu, teori tempatan merupakan sumbangan berharga kepada tamadun bangsa Melayu itu sendiri.

\section{RUJUKAN}

Abdul Halim Ali. (2012). Konsep estetika bersepadu: Satu kaedah baharu kaedah kritik estetik dalam kesusasteraan Melayu. Pangsura Julai-Disember: 90 - 107. Abrams, MH. (1958). The Mirror and The Lamp. Oxford.

Ainon Mohd., 2011. Panduan menulis novel: Teknik Surah Yusuf. Kuala Lumpur. PTS. Ampuan Haji Brahim Ampuan Haji Tengah. (2009). Fungsi Sastera. Brunei. Dewan Bahasa dan Pustaka.

Awang Azman Awang Pawi. (2016). "Produksi sosial dalam konstruksi kepengarangan Jasni Matlani". Dewan Sastera Mac: 9 - 14. 
Braginsky, V. I. (1994). Erti keindahan dan keindahan erti dalam kesusasteraan Melayu klasik. Kuala Lumpur. Dewan Bahasa dan Pustaka.

Chong Ah Fok. (2008). Kajian novel-novel terpilih Brunei Darussalam dari perspektif pengkaedahan Melayu, Brunei Darussalam. Dewan Bahasa dan Pustaka.

Hashim Awang. (1989). Kajian sastera: Suatu pendekatan Melayu. Dewan Sastera Disember: 60-63.

Hashim Awang. (1998). Teori dan kritikan kesusasteraan Melayu di Malaysia”. Pangsura Januari-Jun: $116-145$.

Hashim Awang. (2002). Teori pengkaedahan Melayu dan prinsip penerapannya. Kertas kerja Bengkel Kajian Teori Sastera Melayu anjuran Bahagian Teori dan Kritikan Sastera. Jabatan Sastera Dewan Bahasa dan Pustaka pada 28 - 29 Jun di Riviera Bay Resort, Melaka.

Jelani Harun, 2000. "Ilmu Firasat dalam Penghayatan Sastera", Pangsura Julai Disember: $14-42$.

Liu, James J.Y. (1995). Teori kesusasteran Cina. Terjemahan Lim Kim Hui. Kuala Lumpur. Dewan Bahasa dan Pustaka.

Maman S Mahayana. (2012). Pengarang tidak mati. Nuansa Bandung.

Mana Sikana. (2006). Kritikan sastera Melayu moden. Singapura: Pustaka Karya. Morsidi Mohammad, 2004. Antara deru ombak karya Yukio Mishima dengan empangan karya Muslim Burmat: Unsur alam yang mendominasi makna. Kertas Kerja Seminar Asia Timur dan Dunia Melayu di Hotel Hamilton, Seoul, Korea Selatan anjuran DBP Malaysia dengan kerjasama Hankuk University of Foreign Studies, 9-12 Mei.

Muhammad Haji Salleh. (2000). Puitika sastera Melayu. Kuala Lumpur. Dewan Bahasa dan Pustaka.

Muhammad Haji Salleh. (2014). Perpustakaan itu Tanah Airku. Dewan Sastera, November: $39-41$.

Norhayati Ab Rahman. 2002. "Teori Pengkaedahan Melayu Dalam Puisi Melayu Moden”, Kertas Kerja Bengkel Kajian Teori Sastera Melayu anjuran Bahagian Teori dan Kritikan Sastera Jabatan Sastera Dewan Bahasa dan Pustaka pada 28 - 29 Jun di Riviera Bay Resort, Melaka.

Shahnon Ahmad. (1993). Sastera sebagai seismograf kehidupan. Kuala Lumpur. Dewan Bahasa dan Pustaka

Shahnon Ahmad. (1997). Ranjau sepanjang jalan. Kuala Lumpur: Utusan Publications \& Distributors Sdn. Bhd.

Wellek, Rene and Austin Warren. (1988). Teori kesusasteraan. Diterjemah oleh Wong Seng Tong. Kuala Lumpur: Dewan Bahasa dan Pustaka.

Zurinah Hassan. (2010). Unsur alam dalam puisi Melayu moden. Kuala Lumpur. UKM. 